\title{
LETTERS
}

\section{Fish processing and human infection}

Majere and Cortina present the details of an interesting wound infection, likely acquired from tilapia fish. ${ }^{1}$ Infections from fish processing are varied and have been previously reviewed. ${ }^{2,3}$ Evidently, many bacteria are capable of contaminating the natural environment; they reside in aquaculture systems or are natural microbial flora of fish, and thereafter affect humans.

One of the more interesting outbreaks of tilapia-associated human infection in Canada was that reported by Weinstein and colleagues some two decades ago. ${ }^{4}$ In this context, Streptococcus iniae was identified as a relatively novel pathogen. $S$. iniae may be underrecognized because of its unique microbiological profile, as detailed by the authors.

The number of serious human infections acquired from fish is very small, considering the numerous day-to-day contacts that Canadians have with fish through agriculture, processing or recreational instances. Nevertheless, the use of gloves during the processing of raw food products is likely to reduce adverse outcomes.

\section{Nevio Cimolai MD}

Professor, Department of Pathology and Laboratory Medicine, Children's and Women's Health Centre of British Columbia, Vancouver BC

- Cite as: CMAJ 2017 November 13;189:

E1400. doi: 10.1503/cmaj.733359

\section{References}

1. Majere RA, Cortina S. Necrotizing wound infection from a tilapia fish injury. CMAJ 2017;189:E539-41.

2. Reilly A, Kaferstein F. Food safety and products from aquaculture. J Appl Microbiol 1998;85(Suppl 1):249S-57S.

3. Hastein $\mathrm{T}$, Hjeltnes B, Lillehaug A, et al. Food safety hazards that occur during the production stage: challenges for fish farming and the fishing industry. Rev Sci Tech 2006;25:607-25.

4. Weinstein MR, Litt M, Kertesz DA, et al. Invasive infections due to a fish pathogen, Streptococcus iniae. N Engl J Med 1997;337:589-94.

Competing interests: None declared. 